\title{
Super Extended Calix[4]pyrroles as Candidate for Binding Mercury
}

\author{
MAAN AL-NUAIM \\ Pharmaceutical chemistry department, Basra University, Republic of Iraq. \\ ${ }^{*}$ Corresponding author E-mail: maanswaid771@ hotmail.com \\ http://dx.doi.org/10.13005/ojc/340615
}

Received: October 17, 2018; Accepted: November 22, 2018)

\begin{abstract}
The binding of mercury $\mathrm{Hg}$ (II) by calix[4]pyrrole derivative; 2 has been much less discovered than anion complexation. The presence of hydroxyl group in the structure of meso-tetramethyl-tetrakis[2(4-hydroxyphenyl)ethylcalix[4]pyrrole is important for further modifications in the next steps. The modification of the hydroxyl group by the substitution of ester group was carried out to produce the ester derivative for the modified calix[4]pyrrole 2. The ester group would be expected to deliver high electronic contributions in the complexation processes with the guests as well as to increase the solubility of the receptor in different organic solvents. ${ }^{1} \mathrm{H}$ NMR and isothermal titration calorimetric studies revealed that the receptors exhibited strong interaction with mercury cation and the complexation process was driven enthalpically and entropically. Conductance measurements in acetonitrile were carried out to identify the composition of the formed complex from nano isothermal titration calorimetric studies, the thermodynamic parameters for the complexation processes were calculated.
\end{abstract}

Keywords: Calix[4]pyrrole, Complexation, Guest, Conductance, Thermodynamic, Calorimetry.

\section{INTRODUCTION}

In recent three decades, probing and recognizing of an ionic species has become a target in supramolecular chemistry due to their hazardous effect on the environment and for their importance in industrial applications ${ }^{1-7}$. Mercury will be the target in this report ${ }^{8}$. Mercury is a poisonous metallic element exists in nature in various forms and can be transformed from one state to another, it is allocated in soil, rocks, water, air and living systems. It is a toxic material towards organisms and has serious impact on the human health and the environment. The using of metallic mercury or its organic and inorganic derivatives in batteries, thermometers and some of traditional products means that the ecosystem is vulnerable to contaminated with mercury through the discharge of organic and inorganic mercury derivatives in rivers and eventually contaminate fishes, birds and animals and can affect seriously the healthiness of these systems. For instance, it is found that people who are exposed to a high concentration level of methylmercury suffered from severe variation in nerve response and several markers of symptoms can exist. Also, increasing the concentration level of mercury in blood stream leads to trembling hands and numbness or tingling in their lips, tongues, fingers or toes. These markers can

This is an Open Access article licensed under a Creative Commons license: Attribution 4.0 International (CC- BY). Published by Oriental Scientific Publishing Company @ 2018 
start after a long period of the exposure occurred. Therefore, designing and synthesising an artificial macrocyclic compound with a high affinity to bind with the mercury cation strongly and selectively is very important and challenging task ${ }^{9-11}$. Sensing of anions by calix[4]pyrrole receptor was pioneered by Sessler and co-worker when they concluded that per-methylated calix[4]pyrrole at meso position have showed high affinity to bind with halide anions and the complexation process governed by hydrogen bond formation ${ }^{3}$. The synthesising of calix[4]pyrrole containing multiple cavities with more than one active site is very important and can alter positively the chelating behaviour of the calix[4]pyrrole towards different guests ${ }^{12-14}$. The relative large size and heavy mass of mercury compared with halide anions prompted us to think that the addition of functional groups with electron rich moieties and the high contribution for the $\pi$-system delivered by four pyrrolic rings which can be optimised by the conformational changes to be occurred when the calixpyrroles included in a complexation process can alter the complexation behaviours of calix[4]pyrrole and can works as receptor towards mercury cation significantly. Producing of calix[4]pyrrole containing different functional groups with opposite affinity to bind electronically different guests at different positions is a challenging task. Sessler and coworkers ${ }^{15-17}$ have demonstrated that the synthesising functionalised calix[4]pyrrole has affinity to interact with an ion-pair can make the binding affinity of the macrocycle towards the ion pairs stronger because of the increasing of the electrostatic interaction between the macrocycle with the anion and the cation. Also, it was mentioned earlier that the depth of the cavity of the calix[4]pyrrole can gives significant support for the complexation process with different guests ${ }^{18}$. Recently, much interest has been paid to these macrocycles due to their application discovery to work as ion transporter through the biological membrane. Herein, the superextended calix[4]pyrrole with multiple cavities and multiple binding sites synthesised, functionalised and characterised. The functionalisation of the phenolic hydroxyl group by the substitution of ester group was carried out successfully to increase the number of the active sites and to make the cavity deeper which can deliver high electronic contributions in the complexation process with the ions and electron rich guests as well as to increase the solubility of the receptor in different organic solvents by increasing the hydrophilicity of the lower rim. Addition of ester groups is very important due to their known affinity to bind with most of the metal cations and to facilitating the modification process with different functional groups ${ }^{19-22}$. The compound has showed strong interaction with mercury as well as other selected cations and the complexation process stabilised enthalpically and entropically. ${ }^{1} \mathrm{H}$ NMR study have illustrated that the receptor spectrum disrupted after the addition of mercury perchlorate due to host-guest complexation process. Conductance measurements in acetonitrile as dipolar aprotic solvent were carried out for identifying the composition of the complex. Nano Isothermal Titration Calorimeter was used to measure the thermodynamic parameters for the complexation processes which are; change in enthalpy $\Delta \mathrm{H}^{\circ}$, stability constant; Ks, stoichiometry of complexation; $\mathrm{n}$, entropy change; $\Delta \mathrm{S}^{\circ}$ and the change in Gibbs free energy; $\Delta \mathrm{G}^{\circ}$.

\section{MATERIALS AND METHODS}

Chemicals were used during this research, abbreviations and sources are given as follows:

\section{Solvents}

Dichloromethane (DCM), Sigma-Aldrich, $\geq$ $99 \%$ (GC), 24233, Dimethyl sulfoxide (DMSO), Fisher Scientific, 99 \%, E/0850/17, Acetonitrile (MeCN), Fisher Scientific, HPLC grade, 99.99\%. Chloroform $\left(\mathrm{CHCl}_{3}\right)$, Fisher Scientific, Reagent grade, 99\%., Ethanol (EtOH) Fisher Scientific, Reagent grade, 99.98\% v/v., Methanol (MeOH), Sigma-Aldrich, HPLC grade, $99.7 \%$. Acetone $(\mathrm{Me})_{2} \mathrm{CO}$, SigmaAldrich, 99\%, N, N-Dimethylformamide(DMF), Sigma-Aldrich, anhydrous 99.8\%, 22705-6, Tetrahydrofuran, (THF) Scientific, HPLC grade, 99.99\% Diethylether, (Sigma-Aldrich), Hexane(Hex), Fisher Scientific, Laboratory reagent grade., Ethyl acetate (EtAC), Sigma-Aldrich $\geq 99.5 \%$., 1-Methyl2-pyrolidone (NMP), Sigma-Aldrich $97 \%$. The solvents were used in NMR experiments; deuterated chloroform $\left(\mathrm{CDCl}_{3}\right.$, Cambridge Isotope Laboratories, Inc, (D, 99.8\%) + $0.05 \%$ v/v TMS, deuterated dimethyl sulfoxide, $\left(\mathrm{CD}_{3}\right)_{2} \mathrm{SO}$ Cambridge Isotope Laboratories, Inc (D, 99.9\%), deuterated acetonitrile, $\mathrm{CD}_{3} \mathrm{CN}$, Cambridge Isotope Laboratories, Inc, (D, 99.8\%), hydrochloric acid, $\mathrm{HCl}$, Fisher Chemicals, $0.1 \mathrm{M}$ standard solution, potassium chloride, $\mathrm{KCl}$, 
Fisher Chemicals, analytical reagent grade, 99.74 $\%$, sodium hydroxide; $\mathrm{NaOH}, 18-\mathrm{Crown}-6,18-\mathrm{C}-6$, Fluka, $99 \%$, Sodium hydride, $\mathrm{NaH}$, Sigma-Aldrich, $95 \%$, Ethyl bromoacetate, $\mathrm{BrCH}_{2} \mathrm{COOC}_{2} \mathrm{H}_{5} \% 98$ Sigma-Aldrich, 4-(4-Hydroxyphenyl)-2-butanone\% 99 Sigma-Aldrich.

\section{Purification of Solvents}

- Acetonitrile; $\mathrm{CH}_{3} \mathrm{CN}$, was refluxed under a nitrogen atmosphere and distilled over calcium hydride. The middle fraction of the distilled solvent was collected.

- Tetrahydrofuran; THF, was stored over a sodium metal wire for 24 hours. Then it was distilled under nitrogen, using benzophenone as an indicator.

\section{Instruments used}

- $\quad{ }^{1} \mathrm{H}-\mathrm{NMR}$ spectra were taken on a Bruker AC500 NMR spectrometer.

- Conductance measurements were taken by WYNE KERR LCR METER.

- TA Calorimeter.

Synthesis and characterization of the macrocycles:

The superextended compound 1 was synthesised by applying the procedure reported earlier by Danil de Namor et al., ${ }^{23}$ according to the following Scheme and the sodium hydride was used for the esterification reaction. ${ }^{24,25}$
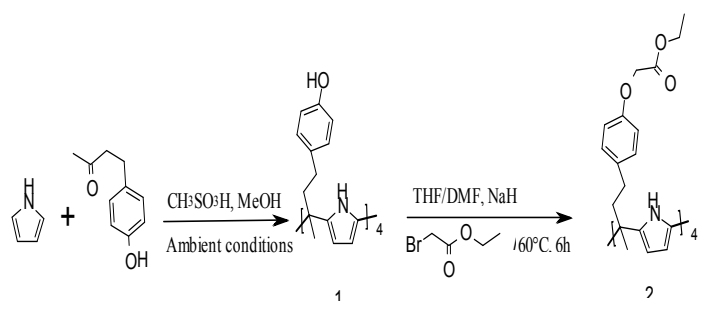

Scheme 1. Synthesis of meso-tetramethyl-tetrakis(4-hydroxyphenylethyl)calix[4]pyrrole 1 and mesotetramethyl-tetrakis-(4-ethylacetatophenoxyethyl) calix[4]pyrrole 2

The 4-[4-hydroxyphenyl]-2-butanone (12.24 $\mathrm{g}, 74.52 \mathrm{mmol}$ ), was dissolved in methanol (100 $\mathrm{ml}$ ) and transferred to a three-neck round bottom flask $(500 \mathrm{ml})$ containing a magnetic stirrer at $25^{\circ} \mathrm{C}$. Methanesulfonic acid ( $1 \mathrm{ml}$ ) was added to the solution and stirred for 30 minutes. Pyrrole $(5 \mathrm{~g}, 74.53 \mathrm{mmol})$ dropwise were added to the reaction solution and the reaction was left overnight. The mixture poured into a beaker containing $200 \mathrm{ml}$ of distilled water and brown solid precipitated. The compound was filtered, dried by air then collected and dissolved in diethyl ether, filtrated to remove the black tar from the solid. The solvent was evaporated and the solid obtained was recrystallized from acetic acid and left to cool. Further purification by using acetone-acetonitrile mixture was applied to get pure white powder, dried in vaccum drier ${ }^{1} \mathrm{H}$ NMR (500 MHz, in d6-DMSO), $\delta$ in ppm), 9.3 (s, NH, $4 \mathrm{H}), 9.09(\mathrm{~s}, \mathrm{OH}, 4 \mathrm{H}), 6.84$ (d, $\mathrm{Ar}-\mathrm{H}, 8 \mathrm{H}), 6.58(\mathrm{~d}, \mathrm{Ar}-\mathrm{H}, 8 \mathrm{H}), 5.78(\mathrm{~d}, \beta-\mathrm{H}$ pyrrole ring, $8 \mathrm{H}), 2.26\left(\mathrm{t}, \mathrm{CH}_{2}, 8 \mathrm{H}\right), 2.05\left(\mathrm{t}, \mathrm{CH}_{2}, 8\right.$ $\mathrm{H}), 1.57\left(\mathrm{~s}, 12 \mathrm{H}, \mathrm{CH}_{3}\right)$. The esterification of 1 have been carried out as follows : in a three-neck round bottom flask $(250 \mathrm{ml})$ containing a magnetic stirrer at room temperature and under an inert atmosphere, meso-tetramethyl-tetakis-(4-hydroxyphenylethyl) calix [4]pyrrole ( $2 \mathrm{~g}, 1.67 \mathrm{mmol}$ ), was dissolved and stirred in a mixture of freshly distilled THF and dry DMF (THF: DMF 60:40, v/v). Then sodium hydride $(0.056 \mathrm{~g}, 2.24 \mathrm{mmol})$, was weighted in a glovebox and added carefully followed by a drop-wise addition of ethylbromo acetate $(0.28 \mathrm{~g}, 1.67 \mathrm{mmol})$. The reaction mixture was heated in an oil bath at $60^{\circ} \mathrm{C}$ under vigorous stirring. The reaction was monitored by thin layer chromatography using a DCM: $\mathrm{MeOH}$ (9:1) mixture as the developing solvent. After the reaction was completed, the mixture was left to cool down to ambient temperature. The solvent was evaporated under reduced pressure and a colourless viscous liquid product was obtained, dissolved and extracted from DCM, it was then washed with distilled water and then with brine. The organic layer was collected and dried over anhydrous magnesium sulphate, filtered and the solvent evaporated using a rotary evaporator. A white powder was obtained, collected and recrystallized from methanol. The white powder obtained, filtered and dried, ${ }^{1} \mathrm{H}$ NMR $\left(500 \mathrm{MHz}\right.$, in $\left.\mathrm{CDCl}_{3}\right), \delta$ (ppm), 7.03(s, NH, $\left.4 \mathrm{H}\right), 6.91$ (d, Ar-Hmeta, 8H), 6.69 (d, Ar-Hortho, $8 \mathrm{H}$ ), 5.95 (d, $\mathrm{C}-\mathrm{H}, 8 \mathrm{H}$ pyrrole rings), 4.54 (s, , O- $\mathrm{CH}_{2}-\mathrm{CO}, 8$ $\mathrm{H}), 4.25$ (q, O- $\left.\mathrm{CH}_{2}, 8 \mathrm{H}\right), 2.30$ (t, $\left.\mathrm{CH}_{2}-\mathrm{Ar}, 8 \mathrm{H}\right), 2.10$ $\left(\mathrm{t}, 8 \mathrm{H}, \mathrm{C}-\mathrm{CH}_{2}\right), 1.53\left(\mathrm{~s}, \mathrm{CH}_{3}, 12 \mathrm{H}, 1.28\left(\mathrm{t}, \mathrm{CH}_{3}\right)\right.$. Elemental analysis was calculated \% (C: $72.7, \mathrm{H}$ : 7.07, N 4.68 found \% (C: 72.19, H: 7.02, N: 3.95). 


\section{${ }^{1} \mathrm{H}$ NMR complexation studies}

In a $5 \mathrm{~mm}$ NMR tube the receptor was dissolved in the deuterated acetonitrile using TMS as the reference solvent. The mercury perchlorate $\mathrm{Hg}\left(\mathrm{ClO}_{4}\right)_{2}$ was dissolved in $\mathrm{CD}_{3} \mathrm{CN}$ and added into the NMR tube containing the ligand dissolved in the same solvent. Significant changes in the chemical shift were observed for the $\mathrm{N}-\mathrm{H}$ proton because of the addition of mercury salt in deuterated acetonitrile $\mathrm{CD}_{3} \mathrm{CN}$.

\section{Conductance Measurements}

The solution of mercury perchlorate in acetonitrile is an electrolytic solution, therefore, monitoring the binding of mercury with the receptor by testing the variation of the electrical behaviour of its solution is a very good strategy to follow the achievement of the complexation process. Conductometric titrations of mercury perchlorate was carried out in dry acetonitrile as dipolar aprotic solvent. A Wayne-Kerr LCR meter auto-balance Universal Bridge type 4300 at $1 \mathrm{kHz}$ was used for conductance measurements. The conductance cell was a Russell-type glass-bodied electrode with a cell constant $1.07 \mathrm{~cm}^{-1}$ determined according to the method described by Jones and Bradshaw ${ }^{26}$ by adding stepwise additions of a solution of potassium chloride in deionised water $\left(0.1 \mathrm{~mol} \mathrm{dm}^{-3}\right)$ into the conductivity cell containing deionised water $(25 \mathrm{ml})$ at $298.15 \mathrm{~K}$, the conductivity values were recorded after each addition. Conductometric titrations involved the gradual addition of the receptor solution in acetonitrile to the conductivity cell containing the mercury perchlorate in the same solvent at $298.15 \mathrm{~K}$. To achieve these measurements, the conductometric cell connected to a thermostatic water bath was loaded with the receptor solution in acetonitrile. Then the electrodes were immersed into the solution cell under continuous stirring of titration. Accurate aliquots of the receptor in acetonitrile were gradually added to the guest solution in the same solvent, the resistance was recorded after each addition, getting constant values of resistant indicates the end of the reaction. The obtained magnitudes were corrected for the conductivity of pure solvent. Plotting of the molar conductance $\Lambda \mathrm{m}\left(\mathrm{S} \mathrm{cm}^{2} \mathrm{~mol}^{-1}\right)$ against the [receptor/ guest] concentration ratio, the stoichiometry of the complexation was identified graphically.

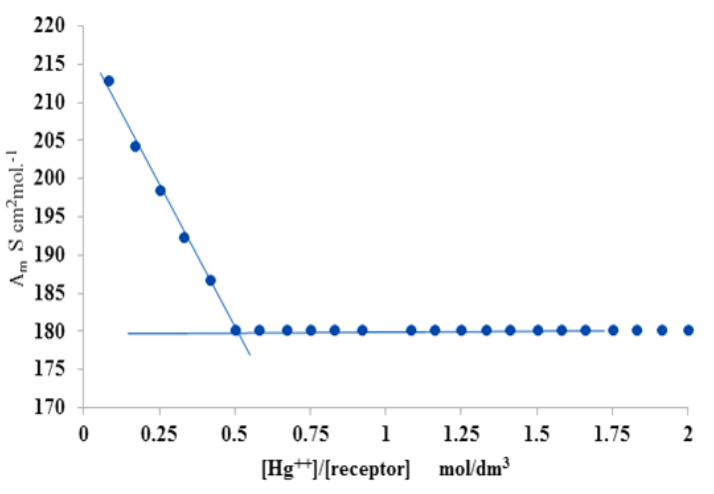

Fig.1. Conductivity measurement for the interaction of $\mathrm{Hg}$ with the receptor

\section{Calorimetric measurements}

Nano ITC is a highly sensitive technique designed to determine rapidly and accurately the thermodynamic parameters associated with the complexation process between the host and the guest in solutions such as stability constant and enthalpy of a reaction. From these parameters, Gibbs free energy and the entropy of the complexation can be calculated by applying the following equations (1\&2)

$$
\begin{aligned}
\Delta G^{\circ} & =\Delta H^{\circ}-T \Delta S^{\circ} \\
\Delta G^{\circ} & =-R T \ln k_{s}
\end{aligned}
$$

Were $G$, is the Gibbs free energy, $H$ is the enthalpy, $S$ is the entropy of the system, $T$ is the absolute temperature in Kelvin and ks is the equilibrium constant of the reaction.

The Nano- ITC measurements were carried out in degassed acetonitrile at $298.15 \mathrm{~K}$. The receptor solution was loaded in a sample cell and the reference cell was loaded by the solvent only. The mercury perchlorate solution was automatically added by injecting $5 \mu \mathrm{l}$ of titrant successively into the host solution in same solvent with a $300 \mathrm{sec}$. interval between each injection. The Nano-ITC type (TA Nanocalorimeter) was used to achieve these measurements and the instrument calibrated before use. Calibration experiments were carried out to check the accuracy of the Nano-ITC. The complexation reaction between barium chloride $\mathrm{BaCl}_{2}$ with 18-crown-6 in aqueous medium at 298.15K was suggested by Wadso as a standard reaction to calibrate the calorimeter. The calibration experiment was carried out by setting the instrument to inject automatically $5 \mu \mathrm{l}$ from the injection syringe containing the aqueous solution of barium chloride 
(15 $\mathrm{mM}$ ) every five min. to the reference cell which was loaded with $18-C r o w n-6$ solution $(1 \mathrm{mM})$ in deionised water. After the completion of the reaction, the data were analysed by the software delivered with the instrument from the manufacturer. From the titration information, the stability constant $\mathrm{K}_{\mathrm{s}}$ and the enthalpy change $\Delta \mathrm{H}$ were obtained. From these parameters, the Gibbs free energy and entropy was calculated and found in a good agreement with values obtained earlier

\section{RESULTS}

\section{${ }^{1} \mathrm{H}$ NMR complexation studies}

In a $5 \mathrm{~mm}$ NMR tube the receptor was dissolved in the deuterated acetonitrile using TMS as the reference solvent. The mercury perchlorate $\mathrm{Hg}\left(\mathrm{ClO}_{4}\right)_{2}$ was dissolved in $\mathrm{CD}_{3} \mathrm{CN}$ and added into the NMR tube containing the ligand dissolved in the same solvent. The NMR experiment were carried out to identify the complexation of mercury with the receptor. Considerable changes were observed, and the receptor peaks strongly disrupted. The results show that the complexation process is fast on the NMR time scale and furthermore suggests that the $\mathrm{Hg}$ (II) cation interacts with the receptor along with the ester groups of the pendent arm. Investigation of the complexation spectrum gives prominent sign about the strength of $\mathrm{Hg}$-receptor binding. This fact is reverberated in the disruption observed in the hall resonance spectrum of the receptor protons. Conductometric titrations in dimethyl sulfoxide were performed, and these are now discussed.

\section{Conductance measurements}

The interaction between the receptor and mercury was investigated using conductance measurements, the stoichiometry of the interaction between the hosted mercury and the receptor were identified. Calix[4]pyrrole containing ester group exhibited high affinity to interact with mercury. The conductivity value of mercuric perchlorate in acetonitrile is relatively high, when the receptor solution is gradually added to this solution the conductivity decreases significantly caused by trapping number of mercury cations by the receptor after each addition to form $\mathrm{CP}-(\mathrm{Hg})_{2}$ complex, the conductivity reaches the lowest value at the equivalence point which indicates the stoichiometric ratio of the complexation. Plotting the $\mathrm{m}$; olar conductance $\Lambda \mathrm{m}\left(\mathrm{S} \mathrm{cm}^{2} \mathrm{~mol}^{-1}\right)$ against [receptor]/ $[\mathrm{Hg}]$ concentration ratio using the graphical tangent method gives the stoichiometry of the complexation, at this point all mercury cations in the solution consumed and the stoichiometric ratio for the reaction to be $2: 1$ [Hg-Receptor] which means that each receptor molecule can host two of mercury cations and this explains that every two of ester group arms can cooperate with each other to host one mercury cation. Due to presence of four of ester group arms, tow of mercury cations was hosted by the $\mathrm{CP}$ - receptor.

\section{Thermodynamics of trapping}

Nano isothermal titration calorimeter was used to investigate the thermodynamic parameters for the interaction of mercury with the receptor. It is a powerful and highly accurate tool for evaluating the thermodynamic parameters correlating to the complexation process which can gives valuable information about the efficiency of the receptor to interact with the targeted guest. Analysing the obtained experimental thermodynamic parameters indicating that the complexation process between mercury and calix[4]pyrrole derivative is enthalpically and entropically favoured ( Table 1). The negative value of enthalpy $\Delta \mathrm{H}^{\mathrm{O}}$ is sufficiently enough to drive the complexation process to form $\mathrm{Hg}$-receptor complex which was confirmed by the conductance measurements, so the positive entropic values indicated that a favourable contribution aided the complexation process by this parameter as a result from the conformational changes of four pendant ester arms to deliver enough energy to complex with the mercury. Thus, the conformational changes are enough to overcome the localisation effect of the solvent dipoles to the charged host-guest complex which can be slowed down the dynamical transportation of the complex in the solution. Also, if we look to second value of entropy we can see that these values is higher positive and governs the interaction of the second mercury cation with the receptor due to the formation of the ionic species which can deliver electrical field to the solution and accelerates the motion of the molecules causing an increasing the number of collisions between the molecules which can cause lose energy and makes the value positive $\left(\Delta \mathrm{H}=3.22 \mathrm{~kJ} \mathrm{~mol}^{-1}\right)$ which is important for complexation to compensate the energy loses as a result from the collisions 
between the molecules and also utilised by the solvent dipoles to reduce the repulsion with the complex through the change of the orientation or by a rearrangement of the ester groups to capture mercury ion. The thermodynamic data obtained from Nano-ITC measurements (Table 1) have showed that the affinity of super extended calix[4]pyrrole to bind with mercury and the complex were enthalpically and entropically stabilised.

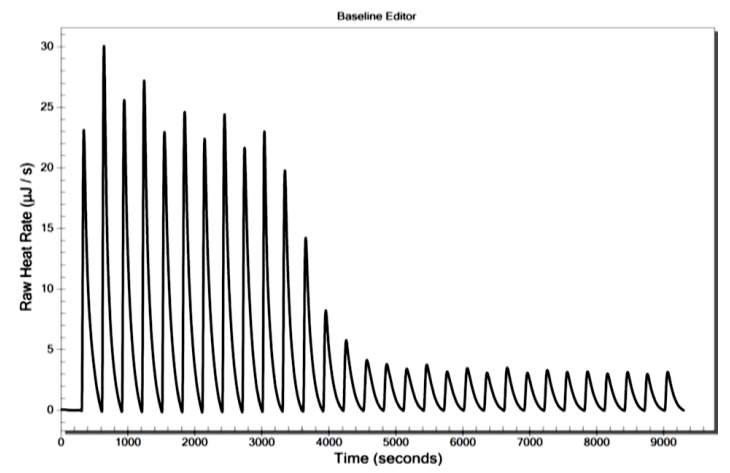

Fig. 2. Isothermal titration calorimetry for the complexation of the receptor in $\mathrm{MeCN}\left(1 \times 10^{-3} \mathrm{~mol} \mathrm{dm}^{3}\right)$ with mercury perchlorate(II) in acetonitrile $\left(2 \times 10^{-2} \mathrm{~mol} \mathrm{dm}^{-3}\right)$ at $298.15 \mathrm{~K}$

Table 1: Physical parameters of the interaction of the receptor and $\mathrm{Hg}$ (II)

\begin{tabular}{lccc}
\hline$\Delta \mathrm{H}^{\mathrm{O}}$ & $\begin{array}{c}\Delta \mathrm{G}^{\mathrm{O}} \\
\mathrm{kJ} \mathrm{mol}^{-1}\end{array}$ & $\begin{array}{c}\Delta \mathrm{S}^{\mathrm{O}} \\
\mathrm{J} \mathrm{mol}^{-1} \mathrm{~K}^{-1}\end{array}$ & $\begin{array}{c}\mathrm{K}_{\text {association }} \\
\mathrm{M}^{-1}\end{array}$ \\
\hline-18.92 & -8.526 & 28.66 & $7.37 \times 104$ \\
3.22 & -33.46 & 112.23 & $3.14 \times 104$ \\
\hline
\end{tabular}

\section{CONCLUSION}

\section{From the obtained results the following conclusions} are drawn

(1) In acetonitrile which is considered dipolar aprotic solvent, the calixpyrrole ester have shown their ability to interact with soft metal cation $\left(\mathrm{Hg}^{2+}\right)$. (2) The flexibility of this calixpyrrole due to the presence of four ester pendant arms which can facilitates the interaction with mercury, this means that the modification process enabled the receptor to interact with mercury as well as the high value of entropy resulted from the conformational changes of the groups. (3), The receptor has ability to discriminates mercury which is an important aspect in the selection of ligands for the removal of toxic ions from water. (4) The fact that this receptor does not interact with biologically essential ions seems to be promising in the search for decontaminating agents for the removal of mercury(II) from non-aqueous solvents and to a much lesser extent from water, once grafted into solid supports. Research in this area is in progress.

\section{ACKNOWLEDGMENT}

The author thankfully to the University of Basra/ College of Pharmacy for the scientific support. There is no any conflict of interest.

\section{REFERENCES}

1. Steed, J and Atwood, J, Supramolecular Chemistry, John Wiley \& Sons., 2009.

2. Davis, F.; Higson, S., Macrocycles: Construction, Chemistry and Nanotechnology Applications, John Wiley \& Sons., 20011.

3. Gale, P.; Sessler; J.; Král, V.; Lynch, V., 1996. 118, 5140-5141.

4. Sessler, J, Gross, D.; W. Cho, W.; Schmidtchen, V; Bates, G.; Gale, P., 2006, 128(37), 1228112288.

5. Danil de Namor, A. F; Webb, O.; El-Gamouz, A; Abu Hamdan, W.; and Al-Nuaim, M., Advanced Synthetic Materials in Detection Science, Chapter 6, RSC., 2014.

6. Woods, C; Camiolo, S.; Light, M.; Coles, S.; Hursthouse, M.; King, M.; Gale, P.; and Essex, J.; J. Am. Chem. Soc., 2002, 124, 8644-8652.
7. Saha I.; and Lee, C., Eur. J. Org. Chem., 2015, 3859-3885.

8. Deamer, D., Microbiol. J., Mol. Biol. Rev., 1997, 61(2), 239-261.

9. Gachter, R.;Wehrli, B. Envir. Sci.Tech., 1998, 32, 3659-3665.

8. Ramon, J.; Lopez-Bes, J.; Marquez, M.; Sessler, J.; Luque, F.; and Orozco, M., Chem. Eur. J., 2007, 13, 1108-1116.

9. Gale, P.; Sessler, J.; Ellen, W.; Tvermoes, N.; Iynch, V., J. Chem. Soc. Chem. Comm., 1997, 665-666.

10. Nishiyabu, R. and Anzenbacher, P., J. Am. Chem. Soc., 2005, 127, 8270-8271.

11. Farinha A.; Tomé, A; Cavaleiro, J., Tetrahedron lett., 2010, 51, 2184-2187.

12. Danil de Namor, A. F.; Abbas, I and Hammud, H., J. Phys. Chem. B., 2007, 111, 3098-3105. 
13. Danil de Namor, A. F. and Khalife, R., Phys. Chem. Chem. Phys., 2010, 12, 753-760.

14. Danil de Namor, A. F. and Shehab, M., J. Phys. Chem. B., 2005, 109, 17440-17444.

15. Kim, D. and Sessler, J., Chem. Soc. Rev., 2015, 44, 532 - 546.

16. Wu, Y.; Wang, D. and Sessler, J., 2001, 66, 3739-3746.

17. Kim, S.; Lynch, V.; Hay, B.; Kim, J.; and Sessler, J., Chem. Sci., 2015, 6, 1404-1413.

18. Gale, P; Anzenbacher, P.; Sessler, J., Calixpyrroles II., 2001, 222, 57-102.

19. Hernández-Alonso, D.; Zankowski, S; Adriaenssens, L., and Ballester, P., Org. Biomol. Chem., 2015, 13, 1022-1029.

20. A. F. Danil de Namor, A. F.; Salazer, L; Tanco, M.; Kowalska. D.; Salas, J.; R. Schulz, R.; J. Chem. Soc. Faraday Trans., 1998, 94, 3111-3115.

21. Danil de Namor, A. F; Chahine, S.; Kowalska, D.; Castellano, E. and O. Piro, , J. Am. Chem.
Soc., 2002, 124, 12824-12836.

22. Sokkalingam, P.; Kim, D.; Hwang, H.; Sessler, J.; and Lee, C., Chem. Sci., 2012, 3, 1819-1825.

23. Bonomo, L.; Solari, E; Toraman, G.; Scopelliti, R.; Laatronico, M. and Floriani, C., Chem. Commun., 1999, 2413-2414.

24. McKervey, M.; Seward, E; Ferguson, G.; Ruhl, B. and S. Harrisc, S. J. Chem. Soc., Chem. Commun., 1985, 388-390.

25. Arnaud, F.; Collins, E.; Deasy, I; Ferguson, GP; Harries, S; Kaitner, B; Lough, F; McKervey, M; Marques, E; Ruhl, B.; Weill, M.; Sewardt, E., J. Am. Chem. Soc., 1989, 3, 8681-8691.

26. Jones, G.; Bradshaw, C., J. Am. Chem. Soc., 1993, 55, 1780-1800.

28. Wadsc, I. and Goldberg. R., Pure Appl. Chem., 2001, 73, 1625-1639.

29. Briggner, L.; Wadsc, I., J. Biochem Biophys Methods., 1991, 22, 101-118. 